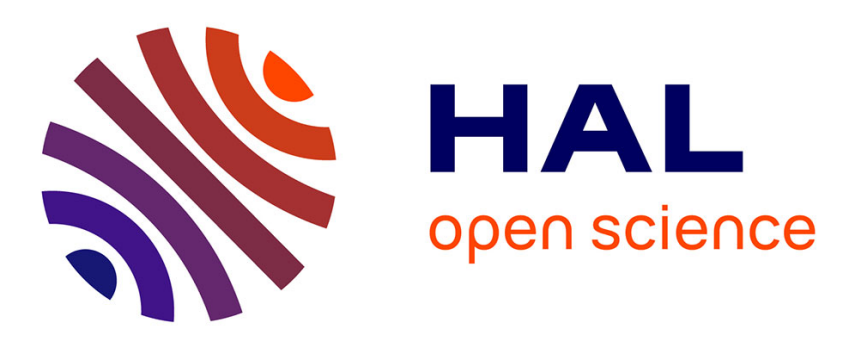

\title{
Does Distance still Matter in Intra-European Partnerships? An Analysis of R\&D Cooperation in Biotechnology
}

Katia Angué, Ulrike Mayrhofer

\section{- To cite this version:}

Katia Angué, Ulrike Mayrhofer. Does Distance still Matter in Intra-European Partnerships? An Analysis of R\&D Cooperation in Biotechnology. 35th Annual EIBA (European International Business Academy) Conference, Dec 2009, Valencia, Spain. 30p. halshs-00690208

\section{HAL Id: halshs-00690208 \\ https://shs.hal.science/halshs-00690208}

Submitted on 22 Apr 2012

HAL is a multi-disciplinary open access archive for the deposit and dissemination of scientific research documents, whether they are published or not. The documents may come from teaching and research institutions in France or abroad, or from public or private research centers.
L'archive ouverte pluridisciplinaire HAL, est destinée au dépôt et à la diffusion de documents scientifiques de niveau recherche, publiés ou non, émanant des établissements d'enseignement et de recherche français ou étrangers, des laboratoires publics ou privés. 
$35^{\text {th }}$ Annual EIBA (European International Business Academy) Conference, University of Valencia, December 13-15 2009

\title{
Does Distance Still Matter in Intra-European Partnerships? An Analysis of R\&D Cooperation in Biotechnology
}

\section{Katia ANGUE and Ulrike MAYRHOFER}

Katia ANGUE, PhD, Associate Professor, Université de La Réunion, GREGEOI research center (IAE), 24-26 rue de la Victoire, 97715 Saint-Denis Messag Cedex 9, France katia_angue@yahoo.fr

Ulrike MAYRHOFER, PhD, Full Professor, IAE Lyon, Université Jean Moulin Lyon 3, Magellan research center, 6 cours Albert Thomas, 69008 Lyon, France ulrike.mayrhofer@univ-lyon3.fr

\begin{abstract}
The objective of this article is to evaluate the influence of several dimensions of distance on the choice of partners for $R \& D$ cooperation. The empirical study is based on a sample of 1.502 agreements signed by European firms operating in biotechnology. The results show that distance still matters in intra-European cooperation. In particular, administrative, geographic, economic and technological distance appears to play a key role, whereas cultural distance does not seem to influence the choice of partners.
\end{abstract}

Keywords: Distance, Intra-European Cooperation, Partner Choice. 


\section{Introduction}

The present study focuses on the compatibility of partners in intra-European R\&D partnerships. More specifically, it concerns the external environment of organizations, with the objective to identify which dimensions determine the choice of partners for cross-border cooperation. In fact, when potential partners are operating in different national environments, the distance between them is likely to shape their choices in terms of cooperation (Hagedoorn, Cloodt and Kranenburg, 2005). Given the growing regional integration, it seems relevant to analyze whether distance still matters when companies choose alliance partners in other European countries.

Distance is a multi-dimensional concept that seems difficult to assess and it is thus necessary to specify its different components. Using the "CAGE (cultural, administrative, geographic, economic) distance framework" proposed by Ghemawat (2001), the present research aims to evaluate the relative importance of the various dimensions of distance on the choice of cooperation partners. The empirical study focuses on $1.502 \mathrm{R} \& \mathrm{D}$ agreements signed by European firms in the biotechnology industry. In the first part, the specific features of European $R \& D$ cooperation and the concept of distance will be examined. The second part is devoted to the presentation of the empirical study and the discussion of results obtained.

\section{The effects of distance in European R\&D cooperation}

Current research on innovation has highlighted a crucial point, being that "essential knowledge, particularly technological knowledge, is unwritten. Thus, some kinds of information can only be transferred effectively between two experienced individuals - through transmission to a receptive individual who has enough expertise to understand it fully, or by physical transfer of the people who are carriers of the knowledge (Oslo Manual, 1997, §82: 22)". However, such transfers of knowledge turn out to be difficult when partners are operating in different environmental contexts. In such cases, distance can make the exchange and creation of knowledge more problematic and 
uncertain. Before defining the concept of distance and its various dimensions, it seems necessary to analyze the specific characteristics of European R\&D cooperation.

\subsection{Characteristics of European $R \& D$ cooperation}

In the context of economic globalization and increasing regional integration, many companies enter into cooperation agreements in the field of research and development (R\&D). Following Mothe (2001), R\&D cooperation can be defined as relating to agreements signed between independent organizations (private enterprises or public research laboratories) bringing together tangible and intangible resources and skills in order to conduct a common $R \& D$ project. The goals pursued are often similar: the sharing of costs and risks linked to the development of new products and processes, the acquisition and transfer of knowledge and the creation of new knowledge, skills and capabilities (Barthélémy, Fulconis and Mothe, 2001; Hagedoorn and Narula, 1996). Given the risks intrinsic to any cooperative project, the achievement of the goals as initially defined can be problematic. In fact, R\&D agreements are frequently subject to tension which the partners can prevent by carefully choosing their allies (Puthod and Thévenard-Puthod, 2006).

Conducting a cooperative project will prove to be more difficult if the companies involved are operating in different national environments. This is because divergence in the behavioral reactions of the 'allies' is likely to generate conflicts, possibly resulting in failure. However, the globalization of markets and competition obliges firms to build networks of relationships with local actors in other countries. Many enterprises have for this reason built up portfolios of alliances associating actors around the world and involving different activities in the value chain (Ohmae, 2005).

$R \& D$ agreements are usually aimed at transferring and/or creating knowledge whose nature will in most cases be tacit. However, while explicit knowledge can be transmitted fairly easily from one organization to another, the transfer of tacit knowledge is more difficult given that it cannot be transmitted by formalizing it in a language accessible to others. The transfer of tacit knowledge thus requires the implementation of a closer relationship between the companies (Choi and Lee, 1997), which can take the form of a cooperative agreement (Hamel, 1991; Simonin, 1999). 
When a company engages in $R \& D$ cooperation, it is faced with a certain degree of uncertainty arising from the incomplete nature of the contracts signed. It is thus difficult to anticipate the exact nature of the knowledge that will be created by the cooperative project or to determine the use and value of that knowledge. Furthermore, information asymmetry means that a company cannot evaluate in a precise way its partners' ability to create knowledge. This uncertainty seems more important in the case of cross-border cooperation, where the company is involved with a partner operating in a different context (Hagedoorn, Cloodt and Kranenburg, 2005).

In practice, $R \& D$ agreements can bring together two or more organizations from the private and public sectors. Multilateral cooperation on $\mathrm{R} \& \mathrm{D}$ is often conducted within a consortium framework where a grouping of organizations is formed with the aim of conducting common R\&D activities. Participation in a consortium allows the associated firms to access resources that are difficult to transfer and/or to create new resources and skills (Barthélémy, Fulconis and Mothe, 2001). In Europe, consortium formation has been facilitated by the implementation of EU programs such as the Eureka projects, the aim of which is to enhance the competitiveness of European companies, or the multiyear Framework Program for Research and Technological Development.

\subsection{Distance: A multidimensional concept}

When a company decides to enter into a cooperation agreement with a partner based in another country, it will inevitably need to cope with the distance between its home country and the foreign country. However, distance is a multidimensional concept that is difficult to evaluate. In a recent article, Ghemawat (2001) proposes a suitable conceptual framework known as the "CAGE (cultural, administrative, geographic, economic) distance framework" which allows to differentiate four forms of distance: (1) cultural, (2) administrative, (3) geographic and (4) economic. These four forms of distance are likely to influence the cooperative behaviour of firms, and probably their choice of partner(s). In the present study, the model is transposed to cooperative projects, and a fifth dimension (5) is added relating to technology, which may also influence the shape of R\&D agreements (Hagedoorn, Cloodt and Kranenburg, 2005). 
Cultural distance results from a range of factors such as language, ethnicity, religious belief, and social norms. It influences the way in which individuals interact with each other and with companies and institutions (Ghemawat, 2001). Cultural distance expresses the degree of separation between two national cultures, in other words, between two systems of ideas and values shared by the members of a given group. This distance is often measured by the index proposed by Kogut and Singh (1988), which allows to calculate the cultural distance between different countries. The index is based on the results observed by Hofstede (2001) for four cultural dimensions: 'Power Distance' (which reflects the distance between different hierarchical levels within an organization and the way in which inequality between individuals is perceived); 'Uncertainty Avoidance' (which measures the degree of tolerance with respect to uncertainty resulting from an unknown future); 'Individualism' (which refers to the relationship between individuals and groups) and 'Masculinity' (which concerns a society's allocation of roles between men and women).

According to Kogut and Singh (1988), cultural distance $\mathrm{DC}_{\mathrm{jk}}$ between country $j$ and country $k$ can be calculated using the following formula:

$$
\mathrm{DC}_{\mathrm{jk}}=\frac{\sum_{\mathrm{i}=1}^{4}\left(\frac{\left.\mathrm{I}_{\mathrm{ij}}-\mathrm{I}_{\mathrm{ik}}\right)^{2}}{\mathrm{~V}_{\mathrm{i}}}\right\}}{4}
$$

where: $\mathrm{I}_{\mathrm{ij}}$ is the index for cultural dimension $i$ determined for country $j$,

$\mathrm{I}_{\mathrm{ik}}$ is the index for cultural dimension $i$ determined for country $k$, and

$\mathrm{V}_{\mathrm{i}}$ is the variance in the index for cultural dimension $i$.

This formula allows to give a precise value to cultural distance between different countries. Nevertheless, it is important to emphasize that the results need to be interpreted with some caution, since the index is based exclusively on empirical investigations by Hofstede. Indeed, the concepts of culture and cultural distance are reflections of a complex reality that is difficult to assess and to evaluate. While the impact of cultural distance on international corporate development is currently the subject of considerable debate (Brouthers and Brouthers, 2001; Shenkar, 2001), a meta-analysis of available empirical studies confirms that a large cultural distance will generally reduce the capital 
commitment of companies to international operations (Tihanyi, Griffith and Russell, 2005). One can thus hypothesize that cultural distance is negatively associated with the willingness of companies to engage in cooperative $R \& D$ projects.

Hypothesis 1. The higher the cultural distance between countries, the less willing companies will be to form $R \& D$ partnerships.

Administrative (or political) distance relates essentially to history, membership of different political, economic or monetary unions (for example, increasing integration in the European Union is reducing the administrative distance between member states of the EU), possible political hostility, government policy and the institutional context (e.g. legislative framework, relations between social partners) (Ghemawat, 2001). This dimension can be measured by using a range of indicators reflecting the degree of intervention by public authorities, the country's legal structure and its level of political risk. Major differences between the institutional contexts of partners will usually make cooperation more difficult (Parkhe, 1991). When entering into a cooperative R\&D project, a company needs to pay particular attention to its partner's legislative framework. Indeed, national legislative systems continue to show substantial differences (legislation on patents, contract performance, for example), which can be a major impediment to R\&D cooperation (Hagedoorn, Cloodt and Kranenburg, 2005). Substantial legal distance is therefore likely to limit companies' willingness to engage in R\&D cooperative projects.

Hypothesis 2. The higher the administrative (or political) distance between countries, the less willing companies will be to form $R \& D$ partnerships.

Geographic distance is the physical distance existing between countries or geographic spaces in which the partners are operating. It results from a range of factors such as physical distance, absence of a common national border, absence of access by sea or river, the size of the country, its transport and communications infrastructures, and climatic differences. Such factors are likely to 
generate additional costs such as those arising from transport and communication (Ghemawat, 2001). Geographic distance can be assessed on the basis of several factors such as the distance in kilometers between the capitals of the countries and whether they share a common border. The costs generated by geographic distance will be particularly significant in the case of activities requiring a high level of coordination, which is the case for $R \& D$ partnerships. In addition, geographic distance makes the transfer of knowledge more difficult between different entities because personal contacts and interaction of teams will be less frequent (Hansen and Lovas, 2004; Shenkar, 2001). Therefore, one can assume that geographic distance is likely to reduce the willingness of companies to enter into $R \& D$ cooperation agreements.

Hypothesis 3. The higher the geographic distance between countries, the less willing companies will be to form R\&D partnerships.

Economic distance results from differences between countries in terms of their economic wealth as well as the cost and quality of the available natural, financial and human resources (Ghemawat, 2001). Economic distance between countries can be quantified using a number of indicators such as the Gross National Product (GNP) or the degree of openness to international trade. It can be calculated using data from international organizations such as UNCTAD, OECD or the World Bank. The economic environment and the availability of resources play a key role where R\&D is concerned and it can be assumed that companies will prefer to collaborate with partners whose economic environment is similar to that of their home country.

Hypothesis 4. The higher the economic distance between countries, the less willing companies will be to form $R \& D$ partnerships.

And lastly, technological distance refers to the different levels of technological development in the partners' countries. This dimension is dependent on the comparative scope of the countries' national systems for innovation and the presence of technology-intensive industries, but also on the 
number of patents filed, and the comparative levels of participation in international research programs (Hagedoorn and Narula, 1996). Levels of technological development can be defined using various criteria such as the scale of expenditure on R\&D, national innovative capacity (Porter and Stern, 2001) or numbers of patents filed within the country concerned. The empirical study conducted by Hagedoorn, Cloodt and Kranenburg (2005) highlights the role played by technological distance in the performance of $R \& D$ agreements. This can indeed be a major impediment to setting up a cross-border cooperative project. One can thus hypothesize that technological distance will reduce a company's willingness to enter into R\&D partnerships.

Hypothesis 5. The higher the technological distance between countries, the less willing companies will be to form R\&D partnerships.

\section{Presentation of empirical study}

The empirical study conducted for this research focuses on cooperation agreements in the $R \& D$ field concluded by European firms operating in the biotechnology industry. Biotechnology is defined as the use of the properties of the living world for the production of materials or services intended for the living world. This is par excellence a sector with a network structure (Owen-Smith, Riccaboni, Pammolli and Powell, 2002) and one in which the size of an operator's portfolio of agreements is crucial (Gilsing and Noteboom, 2005). It offers a rich field for studying cross-border partnerships, especially in regard to the examination of the various dimensions of 'distance' described above.

\subsection{Methodology and operationalisation of concepts}

The hypotheses formulated are tested on a sample of $1.502 \mathrm{R} \& \mathrm{D}$ partnerships established by European biotechnology firms. The data used is extracted from a database compiled in the context of wider research on choices of suitable partners for R\&D collaboration in life sciences. This database 
contains information on three types of $R \& D$ cooperation signed by European biotechnology firms with other industrial enterprises or scientific institutions over the period 1992-2000:

- Multilateral cooperative programs undertaken under the EU's Framework Programs for Research and Technological Development partly supported by EU subsidies.

- Various projects conducted under the Eureka label in the medical and biotechnology domain and financed in most cases by means of repayable fund advances provided by the partners' national governments.

- Other agreements relating to $R \& D$, whether these were subsidized at national level or not, and irrespective of the status of the partners or the terms of the contract.

It is worth noting that for all the cooperative programs surveyed, only those involving at least one private company were taken into account. The chosen sample concerns agreements signed by partners based in one of the 15 European countries most active in the biotechnology field ( $c f$. Annex A). Table 1 shows a detailed breakdown of the sample used.

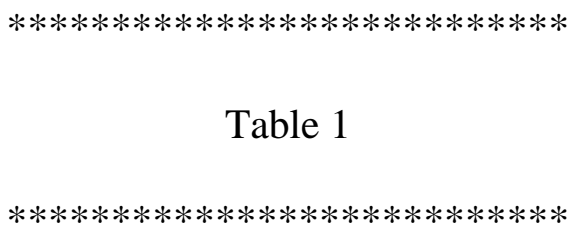

In practice, the authors counted the number of two-by-two pairings established between each pair of countries, or in other terms the numbers of co-participations between organizations. This is because in order to examine the impact of distance on partner choice, an analysis of co-participations (or the two-by-two pairings) rather than projects was considered to be more useful, most notably because it enables multilateral projects to be analyzed. Moreover, a similar approach had already been employed for an analysis of the alliances established under the EU Framework Program (e.g. Charlet, 2001), as well as in the context of Eureka consortia (e.g. Hagedoorn and Schakenraad, 1993; Cabo, 1997). 
Consequently, the dependent variable corresponds to the Jaccard index for co-participation in EU Framework Program projects, in the Eureka program and other "non-framework" cooperative projects, relating to $R \& D$ activities. In fact, this index proves to be well-suited to comparisons between co-participation profiles and provides a clearer idea of the affinities existing between partners of different nationalities than simply adding up the links established between them. Its use is also justified by the fact that by weighting the links established it becomes possible to circumvent the 'size' effect due to the non-uniform intensity of the participation of the different countries in the three contexts for collaboration described above (Cabo, 1997). In fact, divergence between the numbers of participations by organisations in the three contexts under consideration is in some cases substantial, especially for EU Framework Program projects, in which Germany, France and the United Kingdom account for most participations (Charlet, 2001). The index allows two-by-two affinity comparisons to be made, putting into perspective values that are comparable for each of the pairings considered. In practice, the Jaccard index for the co-participations is calculated using a count of the pairings involved in the projects examined based on the number of cases in which at least one of the two components of the pair is present:

$$
\text { Jaccard index } x_{i j}=\frac{c_{i j}}{c_{i}+c_{j}-c_{i j}}
$$

where $\quad c_{\mathrm{ij}}$ : is the number of co-participations for country $i$ and country $j$, $\mathrm{c}_{\mathrm{i}}$ : is the total number of country $i$ participations, $\mathrm{c}_{\mathrm{j}}$ : is the number of country $j$ participations.

This means $\frac{n \times(n-1)}{2}$ pairings per project involving $n$ partners: a project with two partners (one French and one German for example) will thus form a single pairing and therefore a single coparticipation. Conversely, a project involving five partners (i.e. one German, one French, one Belgian, one Swiss and one Dutch) will form ten pairings, and so on. For a study covering 15 countries, the number of potential pairings is therefore 105 .

To be more precise, three Jaccard indices were calculated for the whole series of 105 pairings in the three collaborative contexts, yielding in each case a similarity matrix summarizing in line and column form the countries selected for the study, and in which cell $c_{i j}$ indicates the sum of the number of pairings identified between partners of nationality $i$ and nationality $j$. As a reflection of the intensity 
of the links between pairs created in the three contexts of $R \& D$ cooperation, the sum of these indices turns out to be suitable for the operationalisation of the dependent variable.

The objective of this research is to explain such co-participations in $R \& D$ agreements on the basis of the different dimensions of distance. The distances between a partner in country $i$ and a partner based in country $j$ were calculated as follows:

$$
\text { Dist }_{i j}=\frac{\left(\text { score }_{i}-\text { score }_{j}\right)^{2}}{\sigma_{\text {distrib }^{2}}{ }^{2}}
$$

In order to determine cultural distance separating partners cooperating in the R\&D field, the Hofstede Index (IndexH) has been employed both in its synthetic aggregate version and for each dimension (PDI, IDV, UAI and $M A S)$.

The measurement of administrative distance has proved to be more problematic, given the lack of large-scale empirical studies focusing on this dimension. Therefore, it seemed appropriate to selected several indicators. Firstly, in order to approximate the divergence in legal terms between partners in $\mathrm{R} \& \mathrm{D}$ cooperation, the index for the protection of intellectual property rights formulated by Ginarte and Park (1997) was used. This index is based on five sub-dimensions for which each country is awarded a score between 0 and 1 once every five years ( $c f$. Annex B). The unweighted sum of these component values yields a general score on a scale from 0 to 5 . The distance between partners for this dimension (IPR) was calculated using the average of the scores as calculated by Ginarte and Park (1997) and updated by Park and Wagh (2002) for the period of reference for each of the two countries represented. Secondly, three components of the economic freedom indicator published by the Fraser Institute in the annual Economic Freedom of the World (EFW) reports were selected as reflecting the legal and administrative system as a whole (legal), to take account of the degree to which the labor, credit and business markets are regulated (regul) and to include consideration of the monetary policy (soundmoney) of the 15 countries in the sample. The Fraser Institute's data compilations are mainly based on the figures provided by the World Bank and the World Economic Forum (cf. Annex B for the composition and sources of these indicators). Thirdly, a specific variable enabled the size of the differential in political risk to be taken into account. This variable, termed polrisk, reflects the degree 
of corruption or the scale of social conflict affecting the country and corresponds to one of the three sub-indices calculated by the PRS Group, a rating agency, which evaluates the general level of risk in different countries ( $c f$. Annex B).

To assess geographic distance, we have used two variables: distance in kilometers between the capital cities of the countries where the allied companies were based (Cabo, 1997) and a count of the borders shared by their respective countries (Ghemawat, 2001). To be more precise, the figures used were the logarithms of the distance in kilometers (distkm) and the reciprocal of the number of common borders (limitrophe), which were used to avoid problems of heteroscedascity for the first variable and to convert the proximity expressed by the second into a distance coherent with the other explanatory factors in this study.

For economic distance, as suggested by several studies, the Gross National Product (GNP) per capita (gnpc) was used to express the difference between the partners' standards of living. This was supplemented by the distance between the two countries in terms of development $(H D I)$ as calculated by the index published annually by the United Nations in connection with its Development Program and by an assessment of the distance separating the partners in terms of economic risk (ecorisk), using the evaluation contained in the PRS group reports ( $c f$. Annex B). In addition, the distances calculated on the basis of the degree of openness of the economy (openness), measured using the average of imports and exports of goods and services as a ratio of GDP, and the level of exports (trade) rounded out this measurement by expressing the positioning of the partners' countries in terms of international trade.

And lastly, for technological distance, it seemed necessary to take into account the partners' general technological level, but also the degree of maturity of biotechnology in the countries where the organizations associated under the agreement were operating. Five indicators have been chosen: the amount of investment in $R \& D$ made by resident enterprises, research institutes, universities and government laboratories, expressed as a ratio to total GDP (GERD), the size of the population of scientific researchers in relation to total population (popscient), the level of technological accomplishment (TAI) as shown in UNCTAD reports ( $c f$. Annex B) and the number of new 
biotechnology firms $(N E B)$ formed per million inhabitants and the number of biotechnology patent applications filed with the European Patent Office for each of the 15 countries in the sample.

In all, 23 instrumental variables were selected. They are summarized in Table 2, which also contains details of the information sources used to quantify them.

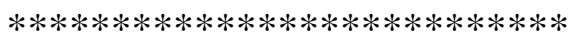

Table 2

*******************************

\subsection{Results and analysis}

Table 3 shows the descriptive statistics and bivariate correlations for all the chosen indicators. Overall, while the vast majority of the explanatory variables tested turn out to be linked negatively to intensity of co-participation in $\mathrm{R} \& \mathrm{D}$ cooperative projects, a small number of exceptions can nevertheless be identified. These relate particularly to the variables legal and regul linked to administrative distance (0.14 and 0.27$)$, testifying to the variety of institutional, legal and administrative contexts in which the partners are operating. The positive sign attached to these correlations does not support hypothesis 2 , which conjectured a negative relationship between the two variables.

In addition, with regard to the dimensions of cultural distance (H1), the correlations appear to be positive and non-significant for two of them: Individualism and Uncertainty Avoidance. This result, which partly differs from that obtained by Cabo (1997) in a study of projects conducted within the framework of the Eureka initiative, without distinction between sectors, seems to be specific to the biotechnology industry. However, several studies emphasize the more or less sizable divergences between results concerning the impact of national culture. In our case, only differences in terms of masculinity and femininity have a significant effect on the partners' propensity for cooperation (0.203) and the role of cultural distance, as measured by the Kogut and Singh (1988) appears to be relatively limited (-0.05). 
However, with the exception of the variables already mentioned, all the other correlations are aligned with the hypotheses formulated above. The analyis also reveals certain problems of multicollinearity between variables independent of the study, justifying the reduction of the data using factorial analysis before applying regression as such. This intermediate data-reduction stage is explained in box 1 .

\section{Box 1: The statistical treatment of the data}

In order to reduce the problems caused by collinearity in the explanatory variables, a few precautions were taken prior to estimating the regression coefficients. The data were first synthesized in a phase involving the reduction of the variables by applying Principal Components Analysis (PCA) successively to each of the concepts. Following this, the application of a stepwise regression method allowed to select the constructs that were most relevant and likely to explain the propensity of companies to engage in cross-border $\mathrm{R} \& \mathrm{D}$ cooperation. Those constructs were then integrated into a regression model optimized in terms of Akaike's Information Criterion (AIC), which selects the most relevant model on the basis of a compromise between bias (which decreases as the number of parameters tested increases) and model parsimony (which requires the data to be described with the smallest possible number of parameters).

The variable reduction stage, whose results are summarized in the annexes, allowed to make a small number of adjustments ( $c f$. Annex C). Specifically, where economic distance is concerned, when PCA is applied to the whole range of variables two main axes are isolated with eigenvalues greater than 1 $\left(\lambda_{1}=2.186\right.$ and $\left.\lambda_{2}=1.537\right)$ : the first combines the variables openness and trade and thus concerns the only aspects related to international economic relations between the countries in which the partners are operating, while the second factor, which is strongly correlated with the three other variables, relates 
more to the internal dimension of the economy. As a consequence, the concept of economic distance was split into two subsidiary concepts: DistEcoExt and DistEcoInt.

Similarly, with regard to the variables linked to technological distance, two sub-concepts emerged from the PCA process $\left(\lambda_{1}=2.308\right.$ and $\left.\lambda_{2}=1.377\right)$ : one linked to the general level of technology in the partners' countries (DistTechG) and the other reflecting the separation between the allied entities in the more specific terms of their degree of maturity or development in biotechnology (DistTechB). Lastly, in light of the inadequacy of the two-by-two correlations between intellectual property rights protection $(I P R)$ and the other variables relating to administrative distance, it was decided to select this variable directly for the regressions without including it in the concept to which it was initially attached (cf. Table 3).

To sum up, seven synthetic concepts (DistCult, DistAdm, DistGeo, DistEcoInt, DistEcoExt, DistTechG and DistTechB) emerging from the PCA, and one initial variable (DistIPR) represent the eight explanatory constructs selected for the regression models.

Initially, several partial 'stepwise' regression models were tested in order to reduce the impact of existing links between the explanatory variables (cf. Table 3) while at the same time verifying the stability of the regression coefficients thus estimated. The results of these different tests are summarized in Table 4, which shows coefficients aligned in the same direction as that indicated by the bivariate correlations. Given the number of explanatory variables considered in this study, the determination coefficients obtained $\left(\mathrm{R}^{2}\right)$ are relatively satisfactory given that they range from 0.25 to 0.36. However, these results need to be considered with some caution due to the existing links between the explanatory variables introduced into the regression models.

Despite this, and although they are consistent with previous results, the estimated coefficients allow to emphasize certain specific features. Indeed, cultural distance, for which only the dimension relating to masculinity appeared to be linked significantly with co-participation in cooperative R\&D projects, is not part of the significant explanatory variables of the regression models. Moreover, the estimations highlight the key role played by specific technological distance between the partners compared with general technological levels. In other words, the degree of maturity in life sciences of 
the countries in which the partners engaged in $R \& D$ cooperation are based seems to have a predominant impact on partner choice. Lastly, the role played by geographic distance appears to be less important in the regression models than in the straightforward two-by-two correlations since the estimated coefficients do not justify consideration of this dimension as having particular importance.

The stepwise regression models provide an initial indication of the predominant distance dimensions for European biotechnology enterprises. Independently of the estimation of the absolute value of the coefficients, it appears from all the 'stepwise' models ( $c f$. Table 4) that distances relating to the culture and external economy of the partners are not significantly related to intensity of coparticipation. For this reason, these two concepts have been removed from the optimized model.

$* * * * * * * * * * * * * * * * * * * * * * * * * * *$

Table 4

$* * * * * * * * * * * * * * * * * * * * * * * * * * *$

The optimized model confirms the coefficients estimated in the previous regressions. It leads to a determination coefficient of 0.368 , which is satisfactory for the number of variables considered ( $F=13.123$, significant for $\alpha=1 \%$ ) and far superior to those obtained in the preceding tests. It appears that the most significant distance dimensions for $R \& D$ cooperation in the biotechnology sector are the following, in descending order of importance:

- those linked to the domestic economy of the partners' countries (DistEcoInt);

- those linked to the level of maturity in biotechnology in the economies in which the partners are operating (DistTechB);

- those linked to the intellectual property rights legislation applicable to the partners (DistIPR);

- those linked to the general level of technology in the countries where the partners are based (DistTechG);

- the geographic distance between the organizations associated under the cooperation agreement (DistGeo) 
In addition, administrative distance is not negatively linked to the propensity to cooperate: on the contrary, partner organizations seem to prefer diversity in this area. The optimized model thus supports hypotheses $\mathrm{H} 2$ and $\mathrm{H} 5$ completely, hypotheses $\mathrm{H} 3$ and $\mathrm{H} 4$ partially, and invalidates hypothesis $\mathrm{H} 1$ relating to cultural distance ( $c f$. Table 5).

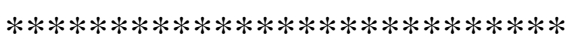

Table 5

$* * * * * * * * * * * * * * * * * * * * * * * * * * *$

The statistical analysis confirms that distance is an important factor in the signing of intraEuropean R\&D agreements, at least in the field of biotechnology. It highlights the relevance of the analytical framework proposed by Ghemawat (2001), demonstrating most notably that distance needs to be observed on the basis of its various component dimensions. In addition, the results support the notion of technological distance, absent from Ghemawat's initial model (2001), thus suggesting that this parameter (T) should be added to the CAGE model.

In effect, in the context of R\&D partnerships in biotechnology, the analysis presented shows that proximity in terms of technology between the countries in which the allied entities are operating is a major factor for the establishment of cooperative $R \& D$ projects. This relates more specifically to their degree of maturity in biotechnology (Gilsing and Noteboom, 2005). This idea of similarity between scientific environments recalls the notion of absorptive capacity developed by Cohen and Levinthal (1989) and the more 'relative' concept formulated more recently by Lane and Lubatkin (1998). It is true that a certain degree of familiarity with a partner's technical and scientific knowledge is required to facilitate its comprehension, its transfer and its full absorption. This proposal is confirmed by Mowery, Oxley and Silverman (1998), who observe that the choice of partners will tend to focus on an organization similar in terms of technological competence. Indeed, Breschi and Lissoni (2004) stress that in order to exchange messages whose tenor is essentially tacit, geographic distance separating the partners is of little importance provided that the level of comprehension is the same on either side. The models tested above make it possible to extend these considerations to the national 
territories in which the allied organizations operate, which, if they are technologically close, can then be considered to favor the establishment of cooperative programs.

Moreover, the results confirm the conclusions reached by Allred and Park (2007) and Porter and Stern (2001). This means that national technological 'potential', which is similar to what Porter and Stern (2001) call the 'national innovative capacity', seems to act as an indicator for the scope, nature and characteristics of organizations' external knowledge. In particular, European businesses prefer to engage with academic or industrial actors working in environments that are similar in terms of research and activity in the life sciences domain. This idea is coherent with the formulation of Cohen and Levinthal (1989) whereby the absorptive capacity of an organization will depend both on its internal R\&D effort and on the expenditure committed by other firms, as well as the level of knowledge present outside the industry in which it operates.

It should be noted that in none of the regression models tested does cultural proximity correlate significantly with propensity for cooperation. This result concords with that of Cabo (1997), who, in the context of Eureka projects in the medical field, had already pointed to the limited impact of the Hofstede dimensions on the intensity of inter-organizational links. More generally, our result supports current controversy as to the impact of cultural distance and its measurement via the index developed by Kogut and Singh (1988). Some authors even suggest that cultural distance might be conducive to cooperation on the grounds that it could be a source of complementarity and a stimulus for creativity (Yeheskel, Zeira, Shenkar and Newburry, 2001). It should be remembered that researchers, irrespective of their countries of origin, form a community whose ramifications stretch around the planet. Indeed, this collective belonging to an extended scientific community of members of organizations involved in 'non-framework' $R \& D$ cooperation agreements is such as to encourage informal contacts and therefore the surmounting of cultural differences that keep partners apart (Sevon and Kreiner, 1998).

As for intellectual property rights, the regression models indicate that distance between allies along this dimension appears likely to discourage the establishment of cooperative relationships. It can therefore be seen that a partner's national environment may not only impede or 
encourage innovation, depending on the legal provisions in force for its ownership (Porter and Stern, 2001), but it may also modulate the intensity of R\&D alliances. This result is compatible with the research conducted by Hagedoorn, Cloodt and Kranenburg (2005), who stress the importance of differences with regard to property rights for the form taken by technological cooperation. The authors conclude that "international differences in terms of protection of intellectual property testify to important differences in technological capacities between countries (Hagedoorn, Cloodt and Kranenburg, 2005: 183)". Likewise, and taking as a basis the assessment of rights in this area developed by Ginarte and Park (1997), Allred and Park (2007) demonstrate that the level of protection provided in a given country relates significantly to the level of innovation in that country. With regard to $R \& D$ agreements, differences in property legislation seem to lead to a higher level of uncertainty concerning the outcome and ownership of the results produced by the collaboration, thus reducing the propensity to cooperate. In other words, European biotechnology firms, particularly sensitive to intellectual property issues, prefer to cooperate with partners whose legislation is similar to their own.

Conversely, unlike the legal aspects and protection of property rights, the various regression models tested highlight the fact that European actors, far from preferring alliances with organizations characterized by similar political and administrative environments, tend to favor diversity. In the biotechnology industry, it seems that administrative distance tends to act as a stimulus for the propensity to cooperate. It is true that the differences are probably less great in absolute terms (given that most of the countries concerned are EU Member States), but this outcome is not less difficult to interpret in the light of current knowledge with regard to administrative differences.

Conversely, the hypothesis on geographic distance turns out to be supported. The findings corroborate the extensive research done on this dimension of distance indicating that the necessary face-to-face interactions involved in most joint $R \& D$ projects are made more difficult by geographic separation (Bélis-Bergouignan, 1997). It is obvious that firms working in the field of biotechnology have understood this well since the exchange of knowledge is evidently more often contemplated by them with a partner based nearby. However, the effects of geographic distance on the intensity of cooperation might be linked to the size - often limited - of European biotechnology enterprises. In fact, it seems to be the case that all economic actors are not governed in the same way by the 
'constraint' of physical or spatial proximity between allies. Where this point is concerned, SMEs seem to be more affected, whereas large corporations, given the scale of their resources, are in a position to replace it by means of artificial solutions (exchanges of personnel for example), recreating a form of geographic proximity that is lacking in reality. For their part, Beise and Stahl (1999) conclude that if links are more intensive in a concentrated geographic area, it is probably more for reasons of convenience and that the notion of spatial proximity is not significant as such. In particular, it would seem to be necessary to verify the extent to which the need for the local embedding of companies is dependent on their size but also on the industry to which the cooperating firms belong.

And lastly, it appears that economic distance also shapes the development of R\&D cooperation agreements. This outcome, clearly highlighting the importance of economic and financial criteria in the definition of corporate relational strategies, is in line with that obtained by Cabo (1997), who observed that in the context of projects established under the Eureka label, there were fewer agreements between countries whose gross national products differed greatly. For example, where Ghemawat (2001) has already seen that differences in terms of the living standards of populations were likely to create a distance prejudicial to trade relations, one can add that such differences are also harmful to the establishment of cooperative R\&D programs in the highly specialized and technical biotechnology domain. Conversely, aspects related to the external economy turn out to have no influence on either the intensity of relationships established between organizations or the forms taken by the alliances (Hagedoorn, Cloodt and Kranenburg, 2005).

\section{Conclusion}

Driven by the globalization of markets and competition, companies build cooperative relationships with actors based in other countries (Arrègle, Hébert and Beamish, 2006). Once a company enters into a cooperation agreement, it is faced with the need to cope with the distance separating it from the local environment of its partner. The analysis presented in this article contributes to a better knowledge of the impact of distance on partner choice in the context of European R\&D cooperation, while at the same time stressing its multidimensional character. It reveals that, even within 
apparently similar countries, several dimensions of distance still have an impact on the propensity of firms to cooperate. The empirical study notably shows that administrative, geographic, economic and technological distances play a key role, whereas cultural distance does not seem to influence the choice of partners, at least in the European biotechnology sector.

The empirical study allows a better understanding of the dominant criteria for partner choice in European $\mathrm{R} \& \mathrm{D}$ cooperation. It highlights the importance of environmental factors for understanding cooperative strategies (Christmann, Day and Yip, 1999). Several recommendations for further research can be identified. Firstly, given the monosectoral nature of this study, it seems necessary to conduct similar research on activities with a technological content that is moderate or very limited. Secondly, there is a need to look in more depth at the various dimensions of the concept of distance in order to identify the most relevant indicators. Similarly, analysis of the existence of a possible 'windfall effect' when subsidized agreements are signed, possibly reflected in lesser sensitivity to certain types of distance where a cooperative project benefits from subsidies from public sources, seems to be an interesting field of research. Especially as - as Sevon and Kreiner most notably have pointed out (1998) - the role of such subsidies is not without influence on the reasons firms give when justifying their engagement in an alliance that is then generally focused more on sharing the costs and risks of the project than on seeking suitable partners. 


\section{References}

Allred, B.B. \& Park, W. G. (2007). Patent rights and innovative activity: Evidence from national and firm-level data, Journal of International Business Studies, 38(6), 878-900.

Arrègle, J.-L., Hébert, L. \& Beamish, P.W. (2006). Modes of international entry: The advantages of multilevel methods, Management International Review, 46(5), 597-618.

Barthélémy, J., Fulconis, F. \& Mothe, C. (2001). Les coopérations inter-organisationnelles: approche théorique et illustrations. In A. Ch. Martinet and R.-A. Thiétart (eds.), Stratégies. Actualité et futurs de la recherche, Paris: Vuibert, 289-302.

Beise, Z. M. \& Stahl, H. (1999). Public research and industrial innovation in Germany, Research Policy, 28(4), 397-422.

Bélis-Bergouignan, M.-C. (1997). Coopération inter-firmes en R\&D et contrainte de proximité : le cas de l'industrie pharmaceutique, Revue d'Économie Industrielle, 81, 59-74.

Breschi, S. \& F. Lissoni, F. (2004). Knowledge networks from patent data: Methodological issues and research targets. CESPRI Working Papers 150, Milan: Universita' Bocconi.

Brouthers, K. D. \& Brouthers, L. E. (2001). Explaining the national cultural distance paradox, Journal of International Business Studies, 32(1), 177-189.

Cabo, P.G. (1997). The knowledge network. European subsidized research and development cooperation. $\mathrm{PhD}$ thesis, Rijksuniversiteit Gröningen.

Charlet, V. (2001). Analyse des participations françaises au cinquième PCRD. Paris: Observatoire des sciences et des techniques (OST), Ministry of Research.

Choi, Ch. J. \& Lee, S. H. (1997). A knowledge-based view of cooperative interorganizational relationships. In P. W. Beamish and J. P. Killing (eds.), Cooperative strategies. European perspectives, San Francisco: The New Lexington Press, 33-58.

Christmann, P., Day, D. \& Yip, G. S. (1999). The relative influence of country conditions, industry structure, and business strategy on multinational corporation subsidiary performance, Journal of International Management, 5(4), 241-265.

Cohen, W.M. \& Levinthal, D.A. (1989). Innovation and learning: The two faces of R\&D, Economic Journal, 99(397), 569-596.

Ghemawat, P. (2001). Distance still matters. The hard reality of global expansion, Harvard Business Review, 79(8), 137-147.

Gilsing, V. \& Noteboom, B. (2005). Density and strength of ties in innovation networks: An analysis of multimedia and biotechnology, European Management Review, 2(3), 179-197.

Ginarte, J. C. \& Walter, P. G. (1997). Determinants of patent rights: A cross-national study, Research Policy, 26(3), 283-301.

Hagedoorn, J., Cloodt, D. \& van Kranenburg, H. (2005). Intellectual property rights and the governance of international R\&D partnerships, Journal of International Business Studies, $36(2), 175-186$.

Hagedoorn, J. \& Narula, R. (1996). Choosing organizational modes of strategic technology partnering: International and sectoral differences, Journal of International Business Studies, 27(2), 265-284.

Hagedoorn, J. \& Schakenraad, J. (1993). A comparison of private and subsidized R\&D partnerships in the European information technology industry, Journal of Common Market Studies, 31(3), 373-390.

Hamel, G. (1991). Competition for competence and inter-partner learning within international strategic alliances, Strategic Management Journal, 12 (Special Issue), 83-103.

Hansen, M. T. \& Lovas, B. (2004). How do multinational companies leverage technological competencies? Moving from single to interdependent explanations, Strategic Management Journal, 25, 801-822. 
Hofstede, G. (2001). Culture's consequences: Comparing values, behaviors, institutions and organizations across nations. London: Sage Publications.

United Nations Development Program (UNDP) (2002). Human development report 2001. Making new technologies work for human development. New York: Oxford University Press.

Kogut, B. \& Singh, H. (1988). The effect of national culture on the choice of entry mode. Journal of International Business Studies, 19(3), 411-432.

Lane, P. J. \& Lubatkin M. (1998). Relative absorptive capacity and interorganizational learning, Strategic Management Journal, 19(5), 461-477.

Mothe, C. (2001). Les implications des coopérations en R\&D, Finance Contrôle Stratégie, 4(2), 91-118.

Mowery, D. C., Oxley, J. E. \& Silverman, B.S. (1998). Technological overlap and interfirm cooperation: Implications for the resource-based view of the firm, Research Policy, 27(5), 507-523.

OECD (1997). Oslo Manual. Proposed guidelines for collecting and interpreting technological innovation data. Paris: OECD, $2^{\text {nd }}$ edition.

Ohmae, K. (2005). The next global stage. Challenges and opportunities in our borderless world. Upper Saddle River: Wharton School Publishing.

Owen-Smith, J., Riccaboni, M., Pammolli, F. \& Powell, W. W. (2002). A comparison of U.S. and European university-industry relations in the life sciences, Management Science, 48(1), 24-43.

Park, W.G. \& Wagh, S. (2002). Index of patent rights, 2000 Update. In J. Gwartney and R. Lawson (eds.), Economic freedom of the world annual report 2002, Vancouver: Fraser Institute, 33-42.

Parkhe, A. (1991). Interfirm diversity, organizational learning, and longevity in global strategic alliances, Journal of International Business Studies, 29(4), 579-601.

Porter M. E. \& Stern, S. (2001). National innovative capacity. The Global Competitiveness Report 2001-2002, New York: Oxford University Press.

Puthod, D. \& Thévenard-Puthod, C. (2006). Coopération, tensions et conflit dans un réseau d'innovation construit autour d'une PME, Revue Française de Gestion, 32(164), 181-204.

Sevón, G. \& Kreiner, K. (1998). Constructing $R \& D$ collaboration. The enactment of EUREKA. Copenhagen: Copenhagen Business School Press.

Shenkar, O. (2001). Cultural distance revisited: Towards a more rigorous conceptualization and measurement of cultural differences, Journal of International Business Studies, 32(3), 519-535.

Simonin, B. L. (1999). Ambiguity and the process of knowledge transfer in strategic alliances. Strategic Management Journal, 20(7), 595-623.

Tihanyi, L., Griffith, D. A. \& Russell, C. J. (2005). The effect of cultural distance on entry mode choice, international diversification, and MNE performance: A meta-analysis, Journal of International Business Studies, 36(3), 270-283.

United Nations Development Program (2000). Human development report 2000. New York: Oxford University Press.

Yeheskel, O., Zeira, Y., Shenkar, O. \& Newburry, W. (2001). Parent company dissimilarity and equity international joint venture effectiveness, Journal of International Management, 7(2), 81-104.

World Bank (1997). World development indicators. Washington, D.C.: World Bank.

World Economic Forum (2000). Global competitiveness report 2000. New York: Oxford University Press. 
Table 1 - Sample structure

\begin{tabular}{|l|c|}
\hline & "Biotech Europe" \\
\hline Number of agreements & 1,502 \\
including: Framework Program (mixed) & 737 \\
Eureka projects & 163 \\
"Non-framework" R\&D agreements & 602 \\
Number of co-participation pairings & $(15 * 14) / 2$ \\
\hline
\end{tabular}


Table 2 - Summary of variables, indicators and data sources

\begin{tabular}{|c|c|c|}
\hline Concept & $\begin{array}{c}\text { Operationalization of scores per country and } \\
\text { associated instrumental variables }\end{array}$ & Sources \& methods \\
\hline Co-participation & $\begin{array}{l}\text { Jaccard index for co-participations in cooperative } \mathrm{R} \& \mathrm{D} \text { projects } \\
\text { entered into under EU Framework Programs, Eureka, or other } \\
\text { than in the framework of these initiatives (CoPart) }\end{array}$ & $\begin{array}{l}\text { Eureka Secretariat, } \\
\text { CORDIS (CD-ROM and } \\
\text { online database) plus } \\
\text { documentary research. }\end{array}$ \\
\hline $\begin{array}{l}\text { Cultural } \\
\text { distance } \\
\text { (C) }\end{array}$ & $\begin{array}{l}\text { - Kogut and Singh index (1988) } \\
\text { - Difference in terms of Individualism (IDV) } \\
\text { - Difference in terms of Power Distance (PDI) } \\
\text { - Difference in terms of Individualism (UAI) } \\
\text { - Difference in terms of Masculinity }(M A S) \\
\end{array}$ & $\begin{array}{l}\text { Hofstede (2001); } \\
\text { Kogut and Singh (1988). }\end{array}$ \\
\hline $\begin{array}{l}\text { Administrative } \\
\text { distance } \\
\text { (A) }\end{array}$ & $\begin{array}{l}\text { - Difference in terms of intellectual property rights }(I P R) \\
\text { - Difference in terms of legal and institutional structures (legal) } \\
\text { - Difference in terms of regulation (regul) } \\
\text { - Difference in terms of monetary management (soundmoney) } \\
\text { - Difference in terms of political risk (polrisk) }\end{array}$ & $\begin{array}{l}\text { - Ginarte and Park (1997), } \\
\text { Park and Wagh (2002); } \\
\text {-EFW (various eds); } \\
\text {-EFW (various eds); } \\
\text {-EFW (various eds); } \\
\text {-International Country Risk } \\
\text { Guide (various eds). }\end{array}$ \\
\hline $\begin{array}{l}\text { Geographic } \\
\text { distance } \\
(\mathrm{G})\end{array}$ & $\begin{array}{l}\text { - Logarithm of the distance in km between capital cities (distkm) } \\
\text { - Reciprocal of the number of common borders between partners } \\
\text { (limitrop) }\end{array}$ & $\begin{array}{l}\text { - Cabo (1997); } \\
\text { - Ghemawat (2001). }\end{array}$ \\
\hline $\begin{array}{l}\text { Economic } \\
\text { distance } \\
\text { (E) }\end{array}$ & $\begin{array}{l}\text { - Difference in terms of GNP per capita (gnpc) } \\
\text { - Difference in terms of openness of the economy (openness) } \\
\text { - Difference in terms of exports as a percentage of GDP (trade) } \\
\text { - Difference in terms of level of development (HDI) } \\
\text { - Difference in terms of economic risk (ecorisk) }\end{array}$ & $\begin{array}{l}\text { - Eurostat (online database) } \\
\text { - OECD Factbook (various } \\
\text { eds) } \\
\text { - OECD (online database) and } \\
\text { World Bank } \\
\text { - Human Development Report } \\
\text { (UNDP, various eds) } \\
\text {-International Country Risk } \\
\text { Guide (various eds). }\end{array}$ \\
\hline $\begin{array}{l}\text { Technological } \\
\text { distance }(\mathrm{T})\end{array}$ & $\begin{array}{l}\text { - Difference in terms of R\&D spending as a percentage of GDP } \\
(G E R D) \\
\text { - Difference in terms of numbers of scientific researchers/per } \\
\text { million population (popscient) } \\
\text { - Difference in terms of technological accomplishments (TAI) } \\
\text { - Difference in terms of new biotech firms/per million population } \\
\text { - DEB) } \\
\text { - Difference in terms of numbers of biotech patent applications } \\
\text { filed with EPO (biopatent) }\end{array}$ & $\begin{array}{l}\text { - OECD Factbook (various } \\
\text { eds) } \\
\text { - OECD (online database) } \\
\text { - Human Development } \\
\text { Reports (various eds) } \\
\text { - Ernst \& Young reports and } \\
\text { OECD } \\
\text { Biotechnology Statistics } \\
\text { (2006) } \\
\text { - EUROSTAT (online } \\
\text { database) }\end{array}$ \\
\hline
\end{tabular}


Table 3 - Descriptive statistics and correlations

\begin{tabular}{|c|c|c|c|c|c|c|c|c|c|c|c|c|c|c|c|c|c|c|c|c|c|c|c|c|c|c|}
\hline & & variable & mean & sd. & 1 & 2 & $2 \mathrm{a}$ & $2 \mathrm{~b}$ & $2 c$ & $2 \mathrm{~d}$ & 3 & 4 & 5 & 6 & 7 & 8 & 9 & 10 & 11 & 12 & 13 & 14 & 15 & 16 & 17 & 18 \\
\hline & 1 & CoPart & 0.03 & 0.02 & 1 & & & & & & & & & & & & & & & & & & & & & \\
\hline & 2 & IndexH & 2.22 & 1.37 & -0.05 & 1 & & & & & & & & & & & & & & & & & & & & \\
\hline & $2 a$ & PDI & 2.44 & 2.87 & -0.09 & 0.63 & 1 & & & & & & & & & & & & & & & & & & & \\
\hline & $2 b$ & IDV & 2.01 & 2.51 & 0.01 & 0.37 & -0.02 & 1 & & & & & & & & & & & & & & & & & & \\
\hline & $2 c$ & UAI & 2.39 & 2.6 & 0.03 & 0.7 & 0.49 & -0.06 & 1 & & & & & & & & & & & & & & & & & \\
\hline \multirow[t]{5}{*}{ C } & $2 d$ & MAS & 2.05 & 2.28 & -0.2 & 0.26 & -0.16 & -0.06 & -0.02 & 1 & & & & & & & & & & & & & & & & \\
\hline & 3 & IPR & 2.19 & 3.01 & -0.15 & 0.01 & -0.06 & 0.14 & -0.08 & 0.02 & 1 & & & & & & & & & & & & & & & \\
\hline & 4 & polrisk & 2.45 & 3.13 & -0.02 & 0.1 & 0.14 & 0.05 & 0 & -0.07 & -0.13 & 1 & & & & & & & & & & & & & & \\
\hline & 5 & legal & 2.36 & 2.8 & 0.14 & 0.27 & 0.37 & -0.11 & 0.3 & -0.13 & -0.16 & 0.74 & 1 & & & & & & & & & & & & & \\
\hline & 6 & soundmoney & 0.24 & 0.27 & -0.3 & -0.2 & -0.12 & -0.03 & -0.15 & -0.1 & -0.01 & -0.15 & -0.06 & 1 & & & & & & & & & & & & \\
\hline \multirow[t]{2}{*}{ A } & 7 & regul & 2.41 & 3.27 & 0.27 & 0.11 & -0.1 & 0.17 & 0.14 & -0.05 & 0.16 & 0.32 & 0.46 & -0.14 & 1 & & & & & & & & & & & \\
\hline & 8 & distkm (ln) & 6.85 & 0.61 & -0.4 & 0.17 & 0.05 & 0.13 & 0.03 & 0.14 & 0.06 & 0.17 & 0.22 & 0.24 & 0.06 & 1 & & & & & & & & & & \\
\hline \multirow[t]{5}{*}{ G } & 9 & limitrop & 0.76 & 0.43 & -0.3 & 0.38 & 0.11 & 0.16 & 0.27 & 0.3 & 0.17 & -0.05 & 0.08 & 0.09 & 0.11 & 0.58 & 1 & & & & & & & & & \\
\hline & 10 & ecorisk & 2.12 & 3.2 & -0.17 & -0.05 & -0.15 & 0.13 & -0.14 & 0.12 & -0.09 & 0.06 & -0.09 & -0.1 & 0.04 & -0.03 & 0.05 & 1 & & & & & & & & \\
\hline & 11 & GNPC & 1.85 & 2.41 & -0.3 & -0.04 & -0.06 & 0.06 & -0.05 & -0.06 & -0.07 & 0.32 & 0.03 & -0.08 & -0.14 & 0.29 & 0.14 & 0.2 & 1 & & & & & & & \\
\hline & 12 & HDI & 1.79 & 2.64 & -0.3 & -0.01 & -0.11 & 0.01 & -0.05 & 0.19 & -0.16 & 0.11 & 0.01 & -0.13 & -0.05 & 0.22 & 0.09 & 0.44 & 0.42 & 1 & & & & & & \\
\hline & 13 & openess & 2.51 & 3.22 & 0.02 & -0.07 & 0.04 & -0.11 & 0.09 & -0.17 & 0.21 & -0.04 & 0.02 & -0.12 & 0.01 & -0.08 & 0.06 & -0.16 & -0.05 & -0.14 & 1 & & & & & \\
\hline \multirow[t]{5}{*}{ E } & 14 & trade & 2.52 & 3.2 & 0.03 & -0.07 & 0.03 & -0.11 & 0.07 & -0.17 & 0.2 & -0.07 & 0.03 & -0.13 & 0.01 & -0.08 & 0.06 & -0.17 & -0.06 & -0.13 & 0.91 & 1 & & & & \\
\hline & 15 & NEB & 1.45 & 1.73 & -0.4 & 0.06 & -0.02 & -0.02 & 0.11 & 0.12 & -0.1 & 0.17 & 0.09 & 0.21 & 0.05 & 0.42 & 0.17 & -0.11 & 0.31 & 0.24 & -0.2 & -0.2 & 1 & & & \\
\hline & 16 & biopatent & 1.89 & 3.18 & -0.2 & 0.11 & 0.07 & -0.08 & 0.25 & 0.03 & -0.13 & 0.1 & 0.03 & -0.03 & 0.02 & 0.12 & 0.11 & -0.03 & 0.3 & 0.02 & -0.14 & -0.16 & 0.39 & 1 & & \\
\hline & 17 & GERD & 2.17 & 2.91 & -0.08 & -0.06 & -0.18 & -0.14 & 0.02 & 0.2 & -0.02 & 0.21 & 0.17 & 0.02 & -0.01 & 0.2 & 0.04 & -0.16 & 0.1 & -0.04 & -0.05 & -0.06 & 0.27 & -0.08 & 1 & \\
\hline & 18 & popscient & 1.02 & 1.26 & -0.3 & -0.13 & -0.16 & -0.01 & -0.16 & 0.1 & -0.04 & 0.04 & 0.12 & 0.75 & -0.04 & 0.37 & 0.2 & -0.09 & -0.08 & -0.03 & -0.15 & -0.15 & 0.31 & -0.12 & 0.35 & 1 \\
\hline $\mathrm{T}$ & 19 & TAI & 1.52 & 2.15 & -0.1 & 0.04 & -0.08 & -0.09 & 0.07 & 0.13 & -0.09 & 0.22 & 0.39 & 0.48 & 0.09 & 0.36 & 0.18 & -0.18 & -0.08 & -0.07 & -0.16 & -0.14 & 0.26 & -0.14 & 0.56 & 0.77 \\
\hline
\end{tabular}


Table 4 - Regression models ${ }^{\circ}$

\begin{tabular}{|c|c|c|c|c|c|c|c|c|c|}
\hline \multirow{2}{*}{ Concept } & \multirow{2}{*}{$\begin{array}{l}\text { Normalised } \\
\text { coefficients }\end{array}$} & \multicolumn{2}{|c|}{ Model 1} & \multicolumn{2}{|c|}{ Model 2} & \multicolumn{2}{|c|}{ Model 3} & \multicolumn{2}{|c|}{ Optimised model } \\
\hline & & Coeff. & $t$ & Coeff. & $t$ & Coeff. & $t$ & Coeff. & $t$ \\
\hline $\mathrm{C}$ & (DistCult) & & & - & & & & & \\
\hline \multirow{2}{*}{$\mathrm{A}$} & (DistIPR) & -0.167 & -2.003 & -0.218 & -2.606 & -0.125 & -1.434 & -0.262 & -3.028 \\
\hline & (DistAdm) & 0.238 & 2.917 & 0.248 & 3.007 & 0.237 & 2.733 & 0.209 & 2.565 \\
\hline G & (DistGeo) & -0.255 & -2.980 & & & -0.269 & -2.885 & -0.125 & -1.779 \\
\hline \multirow{2}{*}{$\mathrm{E}$} & (DistEcoInt) & -0.294 & -3.494 & -0.373 & -4.453 & & & -0.349 & -4.199 \\
\hline & (DistEcoExt) & - & & - & & - & & & \\
\hline \multirow{2}{*}{$\mathrm{T}$} & (DistTechG) & & & -0.243 & -2.955 & -0.127 & -1.405 & -0.201 & -2.391 \\
\hline & (DistTechB) & -0.278 & -3.258 & -0.350 & -4.177 & -0.322 & -3.602 & -0.290 & -3.546 \\
\hline & adjusted $\mathrm{R}^{2}$ & 0.324 & & 0.323 & & 0.252 & & 0.368 & \\
\hline & $\mathrm{F}$ & 10.998 & & 10.969 & & 7.995 & & 13.123 & \\
\hline
\end{tabular}

Greyed-out variables are those which have been removed from the regression model. When stepwise models are used, selection is based on an examination of correlations between explanatory concepts.

' Only significant variables $(\alpha=10 \%)$ are included. 
Table 5 - Results overview

\begin{tabular}{|lll|}
\hline Hypotheses & Results \\
\hline H1: Cultural distance & (C) & Not supported \\
\hline $\begin{array}{l}\text { H2: Administrative distance } \\
\text { Intellectual property rights } \\
\text { Legal and administrative situation }\end{array}$ & $\begin{array}{l}\text { Supported } \\
\text { Not supported }\end{array}$ \\
\hline H3: Geographic distance $\quad(\mathbf{G})$ & Supported \\
\hline $\begin{array}{ll}\text { H4: Economic distance } \\
\text { Domestic economy } \\
\text { External economy }\end{array}$ & Supported \\
H5: Technological distance & $\mathbf{( T )}$ & Not supported \\
$\begin{array}{l}\text { General level of technology } \\
\text { Degree of maturity in the life sciences }\end{array}$ & Supported \\
\end{tabular}


ANNEXES

Annex A - List of countries included in the study

\begin{tabular}{|l|ll|}
\hline \multicolumn{2}{|c|}{ 'Biotech Europe' } \\
\hline Austria & Finland & Italy \\
Belgium & France & Netherlands \\
Germany & United Kingdom & Norway \\
Denmark & Ireland & Switzerland \\
Spain & Iceland & Sweden \\
\hline
\end{tabular}

Annex B - Indicator components

\begin{tabular}{|c|c|c|}
\hline Indicator & Components & Source(s) \\
\hline $\begin{array}{l}\text { Intellectual } \\
\text { Property } \\
\text { Rights }(I P R)\end{array}$ & $\begin{array}{ll}\text { - } & \text { Scope of patent protection (invention patentability) } \\
\text { - } & \text { Duration of protection } \\
\text { - } & \text { Methods available in country for the enforcement of rights } \\
\text { - } & \text { International conventions signed } \\
\text { - } & \text { Absence of restriction on rights and legal means for } \\
\text { enforcement of IPR (e.g. concerning the possibilities for } \\
\text { exploitation, licence agreements, conditions for patent } \\
\text { cancellation). }\end{array}$ & $\begin{array}{l}\text { Ginarte and Park (1997); } \\
\text { Park and Wagh (2002). }\end{array}$ \\
\hline $\begin{array}{l}\text { Legal } \\
\text { structure } \\
(\text { legal })\end{array}$ & $\begin{array}{l}\text { - } \text { Independence of the judicial system } \\
\text { - } \text { Impartiality of the judiciary } \\
\text { - } \text { Protection and enforcement of property rights } \\
\text { - } \\
\text { Role (involvement) of the military in the legislative system } \\
\text { and political processes } \\
\text { - } \quad \text { System integrity } \\
\text { - } \quad \text { Contract performance and application } \\
\text { - }\end{array}$ & $\begin{array}{l}\text { EFW data calculated using: } \\
\text { - WEF, Global } \\
\text { Competitiveness Report; } \\
\text { - PRS Group, International } \\
\text { Country Risk Guide; } \\
\text { - World Bank, Doing } \\
\text { Business. }\end{array}$ \\
\hline $\begin{array}{l}\text { Regulation } \\
(\text { regul) }\end{array}$ & $\begin{array}{l}\text { Credit market regulation: bank ownership, terms of credit, } \\
\text { interest rates and credit control; } \\
\text { - Labour market regulation: minimum wage, regulatory } \\
\text { controls on employee termination and hiring, } \\
\text { unemployment benefits; } \\
\text { - Business and trade regulation: unregulated prices, } \\
\text { conditions for forming new companies, taxation, tax } \\
\text { system and bureaucracy. }\end{array}$ & $\begin{array}{l}\text { EFW data calculated using: } \\
\text {-World Bank, Regulation } \\
\text { survey; } \\
\text {-World Bank, World } \\
\text { Development Indicators; } \\
\text {-World Bank, Doing } \\
\text { Business. } \\
\text {-IMF, International Financial } \\
\text { Statistics } \\
\text {-International Institute for } \\
\text { Strategic Studies, The } \\
\text { Military Balance; } \\
\text {-WEF, Global } \\
\text { Competitiveness Report. }\end{array}$ \\
\hline $\begin{array}{l}\text { Monetary } \\
\text { policy } \\
\text { (sound } \\
\text { money) }\end{array}$ & $\begin{array}{l}\text { - Average growth in money supply over preceding five years } \\
\text { less average annual growth in GDP over the ten preceding } \\
\text { years. } \\
\text { - Variance in inflation rate over preceding five years. } \\
\text { - Inflation rate in recent past. } \\
\text { - Freedom of exchange between the national and foreign } \\
\text { currencies. }\end{array}$ & $\begin{array}{l}\text { EFW data calculated using: } \\
\text {-World Bank, World } \\
\text { Development Indicators; } \\
\text {-IMF, Annual Report on } \\
\text { Exchange Arrangements and } \\
\text { Exchange Restrictions. }\end{array}$ \\
\hline $\begin{array}{l}\text { Political risk } \\
\text { (polrisk) }\end{array}$ & $\begin{array}{ll}\text { - } & \text { Stability of government } \\
\text { - } & \text { Social and economic conditions } \\
\text { - } & \text { Conditions for investment } \\
\text { - } & \text { Internal conflicts } \\
\text { - } & \text { External conflicts } \\
\text { - } & \text { Corruption } \\
\text { - } & \text { Influence of the military } \\
\text { - } & \text { Political influence of religion } \\
\text { - } & \text { Legislative system } \\
\text { - } & \text { Pressure from ethnic groups }\end{array}$ & $\begin{array}{l}\text { PRS Group, International } \\
\text { Country Risk Guide }\end{array}$ \\
\hline
\end{tabular}




\begin{tabular}{|c|c|c|}
\hline & $\begin{array}{ll}- & \text { Democratic accountability } \\
\text { - } & \text { Bureaucracy and stability of institutions } \\
\end{array}$ & \\
\hline $\begin{array}{l}\text { Economic } \\
\text { risk } \\
\text { (ecorisk) }\end{array}$ & $\begin{array}{ll}\text { - } & \text { Per capita GDP } \\
\text { - } & \text { Real growth in GDP } \\
\text { - } & \text { Inflation rate } \\
\text { - } & \text { Budget balance (\% GDP) } \\
\text { - } & \text { Current account balance (\% GDP) } \\
\end{array}$ & $\begin{array}{l}\text { PRS Group, International } \\
\text { Country Risk Guide }\end{array}$ \\
\hline $\begin{array}{l}\text { Level of } \\
\text { Development } \\
(H D I)\end{array}$ & $\begin{array}{l}\text { Life expectancy and health system } \\
\text { - Access to learning and knowledge (school enrolment } \\
\text { and literacy) } \\
\text { - Standard of living for general population } \\
\end{array}$ & $\begin{array}{l}\text { UNDP, Human Development } \\
\text { Report }\end{array}$ \\
\hline $\begin{array}{l}\text { Technological } \\
\text { accomplishm } \\
\text { ents } \\
(T A I)\end{array}$ & $\begin{array}{l}\text { Level of technological creation: per capita number of } \\
\text { patents granted and per capita royalties and licence fees } \\
\text { received from abroad; } \\
\text { - Level of dissemination of recent innovations: per capita } \\
\text { number of computers connected to Internet \& exports of } \\
\text { products with intermediate or high technology content as a } \\
\text { percentage of total goods exported; } \\
\text { - Level of dissemination of older innovations: per capita } \\
\text { number of telephones - landline and mobile - \& per capita } \\
\text { electricity consumption; } \\
\text { - Technological skill base: average length of schooling of } \\
\text { population aged } 15 \text { and over \& gross enrolment rate in } \\
\text { higher education science courses. }\end{array}$ & $\begin{array}{l}\text { Indicator calculated by } \\
\text { UNDP using: } \\
\text {-World Intellectual Property } \\
\text { Organization (2000); } \\
\text {-World Bank (2001); } \\
\text {-United Nations Statistical } \\
\text { Division; } \\
\text {-International } \\
\text { Telecommunication Union } \\
\text { (2001); } \\
\text {-UNESCO reports. }\end{array}$ \\
\hline
\end{tabular}

Annex C -Data reduction

\begin{tabular}{|r|c|c|c|r|r|r|}
\hline Concepts & DistAdm & DistGeo & DistEcoExt & DistEcoInt & Dist TechG & DistTechB \\
\hline Eigenvalue $(\lambda)$ & 2.071 & 1.581 & 2.186 & 1.537 & 2.308 & 1.377 \\
Proportion of variance & 51.774 & 79.034 & 43.712 & 30.741 & 46.154 & 27.543 \\
Variables (correlations with factors) & \multicolumn{3}{|c|}{} & \\
polrisk & $\mathbf{0 . 8 6 0}$ & & & & & \\
legal & $\mathbf{0 . 8 9 6}$ & & & & & \\
soundmoney & -0.261 & & & & & \\
regul & $\mathbf{0 . 6 7 9}$ & & & & & \\
distkm (ln) & & 0.889 & & & & \\
limitrop (inv) & & 0.889 & & & & \\
ccorisk & & & -0.170 & $\mathbf{0 . 6 5 1}$ & & \\
GNPC & & & 0.017 & $\mathbf{0 . 7 7 0}$ & & \\
HDI & & & -0.080 & $\mathbf{0 . 7 7 3}$ & & \\
openess & & & $\mathbf{0 . 9 9 5}$ & -0.049 & & \\
trade & & & $\mathbf{0 . 9 9 6}$ & -0.048 & 0.325 & $\mathbf{0 . 8 0 6}$ \\
NEB & & & & & -0.236 & $\mathbf{0 . 8 5 3}$ \\
biopatent & & & & & $\mathbf{0 . 7 1 5}$ & 0.128 \\
GERD & & & & & $\mathbf{0 . 8 6 3}$ & -0.043 \\
popscient & & & & & $\mathbf{0 . 9 3 4}$ & 0.016 \\
TAI & & & & & \\
\hline
\end{tabular}

